\title{
Oncogenic role of p53 is suppressed by si-RNA bicistronic construct of UPA, uPAR and cathepsin-B in meningiomas both in vitro and in vivo
}

\author{
RESHU GUPTA $^{1}$, VENKATESWARA RAO GOGINENI ${ }^{1}$, ARUN KUMAR NALLA ${ }^{1}$, CHANDRAMU CHETTY $^{1}$, \\ JEFFREY D. KLOPFENSTEIN ${ }^{2}$, ANDREW J. TSUNG ${ }^{2}$, SANJEEVA MOHANAM ${ }^{1}$ and JASTI S. RAO ${ }^{1,2}$ \\ Departments of ${ }^{1}$ Cancer Biology and Pharmacology, and ${ }^{2}$ Neurosurgery, \\ University of Illinois College of Medicine at Peoria, Peoria, IL, USA
}

Received November 5, 2010; Accepted December 1, 2010

DOI: 10.3892/ijo.2011.934

\begin{abstract}
Meningiomas are the most commonly occurring intracranial tumors and account for approximately $15-20 \%$ of central nervous system tumors. Patients whose tumors recur after surgery and radiation therapy have limited therapeutic options. It has also been reported recently that radiation triggers DNA repair, cell survival and cell proliferation, and reduces apoptosis via the induction of cellular protective mechanisms. Earlier studies have reported that proteases such as UPA, uPAR and cathepsin B play important roles in tumor progression. In the present study, we attempted to determine the effectiveness of two bicistronic siRNA constructs pUC (uPAR/cathepsin B) and pU2 (uPA/uPAR) either alone or in combination with radiation, both in in vitro and in vivo models. Transfection of a plasmid vector expressing double-stranded RNA for uPA, uPAR and cathepsin B significantly induced the sub $-\mathrm{G}_{0}-\mathrm{G}_{1}$ cell population by the mitochondrial intrinsic apoptotic pathway. Results showed that pUC efficiently enhanced sub- $\mathrm{G}_{0}-\mathrm{G}_{1}$ phases compared to $\mathrm{pU} 2$ and was more effective. Interestingly, we observed that in IOMM-Lee cell lines, combined treatment of radiation with pUC and pU2 is more effective in comparison to SF-3061 and MN cell lines. We showed that apoptosis caused by these bicistronic constructs involves Bcl-2, Bcl-xL, p53 inactivation, cytochrome $\mathrm{c}$ release from mitochondria and caspase- 9 activation, followed by the activation of caspase- 3 . We also determined that apoptosis caused by $\mathrm{pUC}$ and $\mathrm{pU} 2$ involves a mechanism which includes inactivation of $\mathrm{p} 53$ by its translocation from nucleus to cytoplasm as confirmed by immunofluorescence, which shows the oncogenic potential of p53 in meningiomas. However, the simultaneous RNAi-mediated targeting of uPAR and cathepsin B (pUC), in combination with irradiation, has greater potential application for the treat-
\end{abstract}

Correspondence to: Dr Jasti S. Rao, Department of Cancer Biology and Pharmacology, University of Illinois College of Medicine at Peoria, One Illini Drive, Peoria, IL 61605, USA

E-mail: jsrao@uic.edu

Key words: p53, apoptosis, uPA, uPAR, cathepsin B, caspase ment of human meningioma in comparison to $\mathrm{pU} 2$ by decreasing p53 expression both in vitro and in vivo.

Introduction

Meningiomas are the second most common primary tumor of the central nervous system, arising from the arachnoidal 'cap' cells in the meninges. They constitute $\sim 20 \%$ of all intracranial primary brain tumors and are more frequent in females (1). These tumors are usually benign in nature; however, they can be malignant because of their continued growth impacts surrounding brain tissue. Most meningiomas are effectively addressed by surgical resection. Unresectable, residual tumors after partial resection and recurrent meningiomas are treated with radiation therapy, which is a common treatment for brain tumors where surgery can not be utilized. However, patients who are not candidates for surgery or radiotherapy or whose tumors recur after such treatments have limited therapeutic options (2-4).

Ionizing radiation can elicit an activated phenotype that promotes rapid and persistent remodeling of the extracellular matrix (ECM) through the induction of proteases such as uPA, uPAR, and cathepsin B, which suggests that inhibition of these molecules could be a potential therapeutic approach to improve the efficacy of radiotherapy $(5,6)$. The overexpression of these proteases by irradiation has been detected in various malignancies, including those in the lung (7), rectal (8) and breast (9). Studies performed with in vitro and in vivo experimental models have demonstrated the elevated levels of uPA and its association with the degree of tumor cell invasion (10-12) and apoptosis (13). Prevention of cancer is profoundly dependent on the p53 tumor suppressor protein. The ability of p53 to eliminate excess, damaged or infected cells by apoptosis (14) is vital for proper regulation of cell proliferation in multicellular organisms (15). It has been shown that p53 prevents proliferation of cells with damaged DNA or with a potential for neoplastic transformation (14).

The p53 gene is the most frequently mutated gene in many common human malignancies including tumors of the colon, breast, lung, gastro-intestinal tract, and brain (16-21). In meningiomas, a few recent studies have investigated the 
association of p53 immunoreactivity with the grade of malignancy (22) and recurrence (23) with promising conclusions. These studies suggest a relationship between $\mathrm{p} 53$ overexpression and proliferative potential in malignant meningioma. Our objective was to further elucidate this linkage in meningiomas. Overexpression of UPA, UPAR, or cathepsin B by tumor cells $(14,24,25)$ prompted us to test the possibility that these proteases might regulate p53 in meningiomas, a possibility that to our knowledge has not been explored previously.

In this study, we demonstrated that simultaneous downregulation of UPA, UPAR and cathepsin $\mathrm{B}$ by two bicistronic siRNA constructs, pUC (uPAR/cathepsin B) and pU2 (uPA/ UPAR) either alone or in combination with irradiation induced apoptosis by $\mathrm{Bcl}-2, \mathrm{Bcl}-\mathrm{xL}$ inactivation, cytochrome c release from mitochondria, and caspase- 9 activation, followed by the activation of caspase-3. We also showed that downregulation of uPA, uPAR and cathepsin B by pUC and pU2 reduced p53 expression in meningioma, which clearly demonstrates the oncogenic role of $\mathrm{p} 53$. On the contrary, we found that $\mathrm{p} 38$ played a role of tumor suppressor protein in meningiomas. We concluded that apoptosis may be induced in meningiomas by a mechanism that involves inactivation of $\mathrm{p} 53$ by its translocation to cytoplasm from nucleus by both bicistronic constructs; however pUC was found to be more effective either alone or in combination with irradiation.

\section{Materials and methods}

Ethics statement. The Institutional Animal Care and Use Committee of the University of Illinois College of Medicine at Peoria, Peoria, IL, USA, approved all surgical interventions and post-operative animal care. The consent was written and approved. The approved protocol numbers are 851 dated April 23, 2009 and renewed on May 12, 2010.

Construction of siRNA-expressing plasmids. Two bicistronic constructs expressing siRNA for uPAR/cathepsin B (pUC) and uPA/uPAR (pU2) were constructed using a pcDNA3 vector as described previously by our group, and all vectors were expressed under the control of a CMV promoter (26). A pcDNA3-scrambled vector with an imperfect sequence, which does not form a perfect hairpin structure, was used to develop the scrambled vector used as a control (pSV).

Cell cultures and transfection conditions. IOMM-Lee, MN and SF-3061 meningioma cells were purchased from American Type Culture Collection. All cells were cultured in high glucose containing Dulbecco's modified Eagle's medium. Cultures were supplemented with $100 \mu \mathrm{g} / \mathrm{ml}$ streptomycin, $100 \mathrm{U} / \mathrm{ml}$ penicillin and $10 \%$ fetal calf serum (FCS) and maintained in a humidified atmosphere containing $5 \% \mathrm{CO}_{2}$ at $37^{\circ} \mathrm{C}$. Cells were transfected, either alone or in combination of radiation with pSV, pUC, and pU2 using FuGENE reagent (Invitrogen, Carlsbad, CA) following the manufacturer's instructions. Transfected cells were maintained in serum containing media for $48 \mathrm{~h}$ and for irradiated experiments, transfected cells were further irradiated for $24 \mathrm{~h}$ before use in various procedures. The primary antibodies used for this study were anti-uPAR (R\&D Systems, Minneapolis, MN), p53, Bcl-2, Bcl-xL, cytochrome c, p38, caspase-3, caspase-9 (Santa Cruz Biotechnology, Santa
Cruz, CA), anti-GAPDH (Cell Signaling, Boston, MA) and HRP conjugated secondary antibodies (Biomeda, Foster City, CA).

Fluorescence-activated cell sorter analysis. FACS analysis was performed as described earlier (27). Briefly, all cells were transfected with $\mathrm{pSV}, \mathrm{pUC}$, and $\mathrm{pU} 2$ either alone or in combination with radiation and collected. Cells were washed three times with ice-cold phosphate-buffered saline (PBS), stained with propidium iodide $(2 \mathrm{mg} / \mathrm{ml})$ for half an hour in $4 \mathrm{mM} / 1$ sodium citrate containing 3\% (w/v) Triton X-100 and Rnase-A (0.1 mg/ml) (Sigma, St. Louis, MO) and were analyzed with the FACSCalibur System (Becton-Dickinson Bioscience, Rockville, MD). The percentages of cells undergoing sub- $\mathrm{G}_{0}-\mathrm{G}_{1}$ phases were assessed using CellQuest software (Becton-Dickinson Bioscience).

In situ terminal-deoxytransferase mediated dUTP nick-end labeling assay. After the above-described treatments terminaldeoxytransferase mediated dUTP nick-end labeling (TUNEL) assay was carried out to detect apoptotic cells. Cells were cultured on eight-well chamber slides at a density of $2 \times 10^{3}$ per well. After $48 \mathrm{~h}$ of transfection with two bicistronic constructs and scrambled vector, one set of cells were collected and another set was exposed to irradiation for $24 \mathrm{~h}$. The cells were fixed after termination in $4 \%$ paraformaldehyde for $1 \mathrm{~h}$. TUNEL staining for the detection of apoptotic cells was carried out using the In Situ Cell Death Detection Kit, fluorescein (Roche Molecular Biochemicals, Indianapolis, IN) following the manufacturer's instructions. Slides were allowed to dry in the dark, observed under a fluorescent microscope (model Olympus IX71; Olympus Optical Co.), and photographed. Results were compared with pSV-transfected cells to analyze apoptosis.

Western blot analysis. All meningioma cells were cultured in 100-mm dishes. The cells were transfected with bicistronic constructs (pSV, pUC and pU2) for $48 \mathrm{~h}$ and further irradiated for $24 \mathrm{~h}$ for irradiated experiments. Cell extracts were prepared in ice-cold RIPA buffer $(50 \mathrm{mmol} / \mathrm{l}$ Tris- $\mathrm{HCl}(\mathrm{pH}$ 7.4), $150 \mathrm{mmol} / 1 \mathrm{NaCl}, 1 \%$ IGEPAL, $1 \mathrm{mmol} / \mathrm{l}$ EDTA, $0.25 \%$ sodium deoxy-cholate, $1 \mathrm{mmol} / 1$ sodium fluoride, $1 \mathrm{mmol} / 1$ sodium orthovanadate, $0.5 \mathrm{mmol} / 1 \mathrm{PMSF}, 10 \mu \mathrm{g} / \mathrm{ml}$ aprotinin, $10 \mu \mathrm{g} / \mathrm{ml}$ leupeptin). The protein concentration in each extract was determined by BSA assay (Sigma-Aldrich, St. Louis, MO). Cell extracts were subjected to SDS-PAGE and proteins were transferred to nitrocellulose membranes and probed with primary antibodies that detect cleaved caspase-3, -9, cytochrome-c, Bcl-xL, Bcl-2, p53 uPAR, and p38. The same membranes also were probed to detect GAPDH as a loading control.

Caspase activity assay. The activity assay for caspase-3 and -9 (colorimetric) was performed using a kit (Chemicon International Inc., Temecula, CA) following the manufacturer's instructions. The cells were cultured and transfected with or without radiation as described above. The harvested cells were transferred to 96-well plates and processed according to the manufacturer's instructions. Fold increase in caspase activity can be determined by comparing the OD reading from the induced apoptotic 
sample with the level of the uninduced control. Data was quantitatively represented as fold increase activity of each caspase.

Establishment and treatment of orthotopic intracranial tumors in athymic nude mice. Orthotopic tumors were established through intracranial injection of tumor cells into brains of athymic nude mice. Six animals were used for each group. IOMM-Lee cells were grown in serum-supplemented DMEM media for 2 days and trypsinized. 0.1 million cells were injected into anesthetized nude mice $(50 \mathrm{mg} / \mathrm{kg}$ ketamine, $10 \mathrm{mg} / \mathrm{kg}$ xylazine) using a stereotactic frame.

The animals were maintained for 1 week to allow the tumors to develop and then divided into 6 treatment groups with 6 animals in each group. Alzet mini-osmotic pumps (Durect Corp., Cupertino, CA) containing $150 \mu \mathrm{g}$ of plasmid at a concentration of $1.5 \mu \mathrm{g} / \mu \mathrm{l}$ were set up for each animal. The animals were treated with pSV, pUC, pU2 either alone or in combination with irradiation and allowed to grow for 3-4 weeks. Once the control group showed chronic symptoms, the animals were euthanized by cardiac perfusion - first using PBS and followed by $10 \%$ phosphate-buffered formalin. The brains were removed and stored in $10 \%$ phosphate-buffered formalin and embedded in paraffin as per standard protocol (28).

Immunofluorescence analysis of protein expression in tumor sections. Paraffin-embedded tumor sections were subjected to rehydration by passing through a series of xylene, $100 \%$ and $90 \%$ ethanol. The slides were washed in cold PBS and blocked for $30 \mathrm{~min}$ in $1 \%$ BSA prepared in PBS followed by overnight incubation in primary antibody (p53) at a concentration of $1: 100$ at $4^{\circ} \mathrm{C}$. The slides were then washed three times with $1 \% \mathrm{BSA}$ in PBS for 2 min per wash, and incubated for $1 \mathrm{~h}$ in appropriate fluorescence-labeled secondary antibody. The slides were kept in the dark to avoid exposure to light. Preparations were mounted on slides using DAPI (Sigma) and fields with intense fluorescence were scored for protein expression. All microscopy studies were performed using fluorescent microscope attached to Olympus camera and set to auto.

p53 gene mutation analysis in nude mice treated with control and irradiated meningioma cells in vivo. DNA was isolated from the phenol chloroform method. PCR was done for exons 5,7 and 8 of the p53 gene. Two $\mu 1$ DNA (200 ng), $0.2 \mathrm{Mm}$ dNTPs, $\mathrm{H}_{2} \mathrm{O}, 10 \mathrm{X}$ buffer, $0.25 \mathrm{U}$ Taq polymerase were added, then repeated 40 times using a PCR thermal cycler at $94^{\circ} \mathrm{C}$ for $30 \mathrm{sec}, 60^{\circ} \mathrm{C}$ for $1 \mathrm{~min}$ and at $72^{\circ} \mathrm{C}$ for $1 \mathrm{~min}$. Using $2 \%$ agarose gel electrophoresis amplified products were confirmed. The DNA sequences from each primer were as follows: p53: exon 5, sense: 5'-TACTCCCCTGCCCTCAACAA-3'; antisense: 5'-CATCGCTATCTGAGCAGCGC-3'. Exon 7, sense: 5'-TCT GACTGTACCACCATCCA-3'; antisense:5'-CTGGAGTCTTC CAGTGTGAT-3'. Exon 8, sense: 5'-TGGTAATCTACTGGG ACGGA-3'; antisense: 5'-CGGAGATTCTCTTCCTCTGT-3'. Ten $\mu 1$ PCR product was boiled, cooled with ice, and then observed in electrophoresis using $12.5 \%$ polyacrylamide gel at $200 \mathrm{~V}$ for $5 \mathrm{~h}$. Single band pattern was observed by staining the gel for $5 \mathrm{~min}$ in ethidium bromide.

\section{Results}

Effect of ionizing radiation on apoptosis in meningiomas. To assess the effect of ionizing radiation on apoptosis, all three meningioma cell lines were irradiated with $\gamma$-rays at a dose of 5 and $10 \mathrm{~Gy}$, and FACS analysis was performed to assess sub- $\mathrm{G}_{0}-\mathrm{G}_{1}$ phases after irradiation. We observed that $5 \mathrm{~Gy}$ of $\gamma$-ray irradiation significantly reduced sub- $G_{0}-G_{1}$ phases in IOMM-Lee $(50 \%)$ when compared with control treatment and 10 Gy of irradiation (27.27\%) made them resistant to apoptosis, conversely we detected induced sub- $\mathrm{G}_{0}-\mathrm{G}_{1}$ phases in the $\mathrm{MN}$ and SF-3061 cell line at both 5 and $10 \mathrm{~Gy}$ of irradiation (Fig. 1A). We further examined whether ionizing radiation affects the activation of caspase cleavage in these cells. We found that 5 and 10 Gy of irradiation, induced caspase- 9 and -3 activation in MN and SF-3061 cell lines; however caspase-9/-3 activation was reduced in the IOMM-Lee cell line (Fig. 1B).

Simultaneous down regulation of $u P A, u P A R$ or cathepsin $B$ induces apoptosis in meningiomas. To observe the effect of treatment on radioresistant and radiosensitive cells we elected to conduct further experiments with a radiation dose of $5 \mathrm{~Gy}$ for IOMM-Lee and $10 \mathrm{~Gy}$ for the MN and SF-3061 cell lines. To further test the role of UPA, UPAR and cathepsin B, we silenced these genes by si-RNA-mediated pUC and pU2 bicistronic constructs. We found a significant decrease of UPAR in IOMM-Lee, MN and SF-3061 cells when transfected with $\mathrm{pUC}$ and $\mathrm{pU} 2$ either alone or in combination with irradiation (Fig. 2A). To determine the effect pUC and pU2 on apoptosis of meningioma cells, we measured the apoptotic cells by FACS analysis. Results showed that si-RNA mediated bi-cistronic constructs of uPAR and cathepsin B (pUC) efficiently increased sub- $G_{0}-G_{1}$ phases compared pU2 in all three cell lines. Further, we studied the combined effect of these bicistronic constructs and irradiation on sub- $\mathrm{G}_{0}-\mathrm{G}_{1}$ cell population. We found that the combined treatment of radiation with pUC led to more sub- $\mathrm{G}_{0}-\mathrm{G}_{1}$ phase in IOMM-Lee cells in comparison to the MN and SF-3061 cell lines and found to be more effective in all three meningioma cell lines, when compared with either pSV control (IOMM-Lee, 431\%; MN, 326\%; SF-3061, 229\%), pSV+IR (IOMM-Lee, 830\%; MN, $110 \%$; SF-3061, 54\%), pUC (IOMM-Lee, 135\%; MN, 46\%; SF-3061, 86\%), pU2 alone (IOMM-Lee, 218\%; MN, 67.9\%; SF-3061, 140\%), pU2+IR (IOMM-Lee, 50\%; MN, 12\%; SF-3061, 20\%) (Fig. 2B). As a confirmatory test, a TUNEL assay was used to detect apoptosis either alone or in combination with radiation in IOMM-Lee, MN and SF-3061 meningioma cell lines. We observed greater number of apoptotic cells with pUC compared to pU2 in all three cell lines; however combined treatment of irradiation with pUC showed greater increase of apoptotic cells in IOMM-Lee cells in comparison to MN and SF-3061 cell lines (Fig. 2C).

si-uPA/uPAR and cathepsin B downregulates the expression of pro-apoptotic proteins and upregulates anti-apoptotic proteins in vitro. Meningioma cells transfected with $\mathrm{pUC} / \mathrm{pU} 2$ either alone or in combination with irradiation led to increased pro-apoptotic protein expressions such as cytochrome c. However, the anti-apoptotic protein, Bcl-xL and Bcl-2 expression was found to be decreased by treatment. This 
A
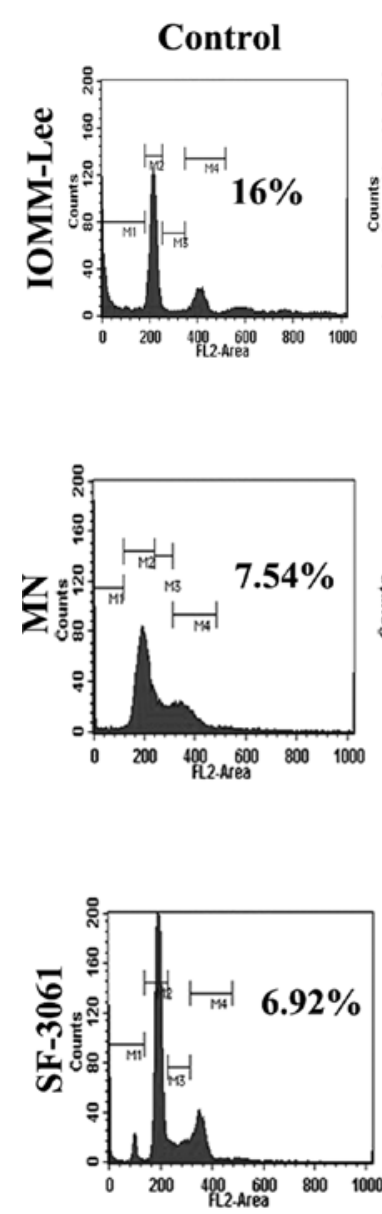

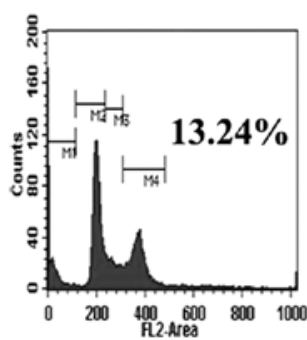

5gy

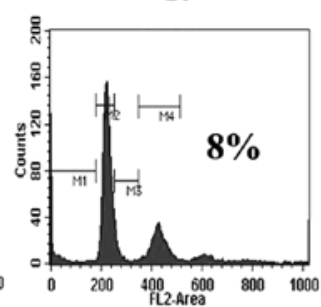

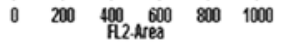

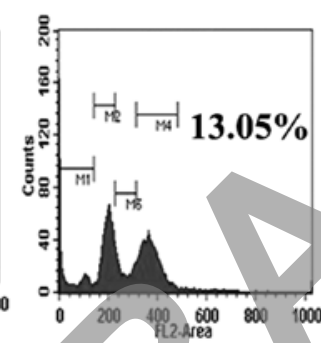

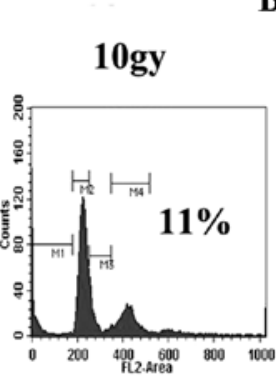

B $\quad 5 g y \quad 10 g y$
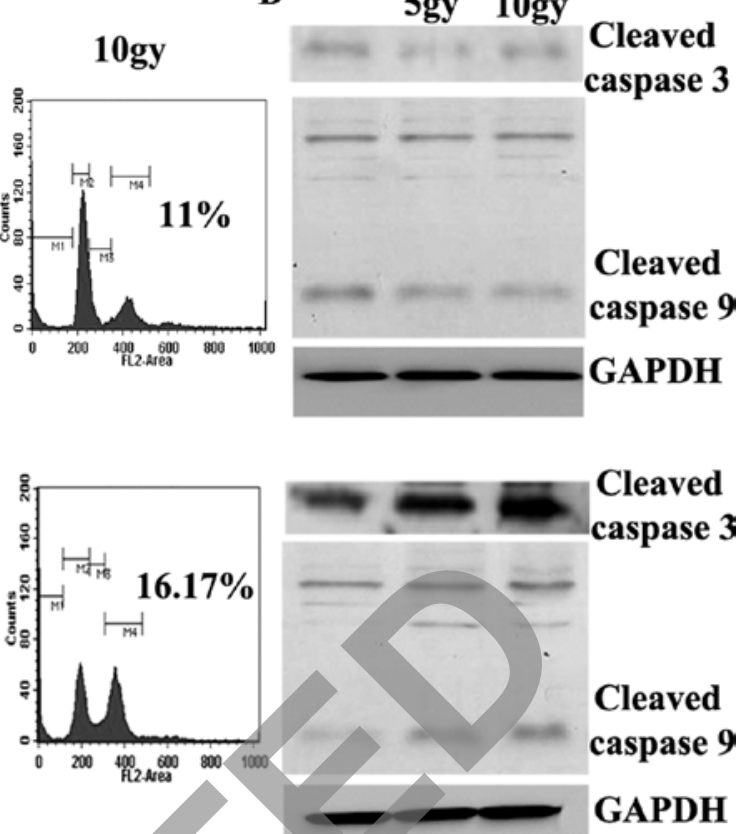

GAPDH

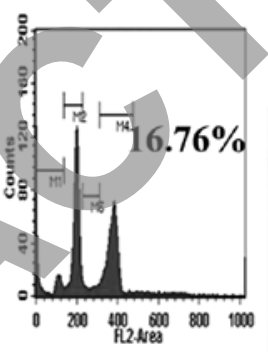

Cleaved caspase 3

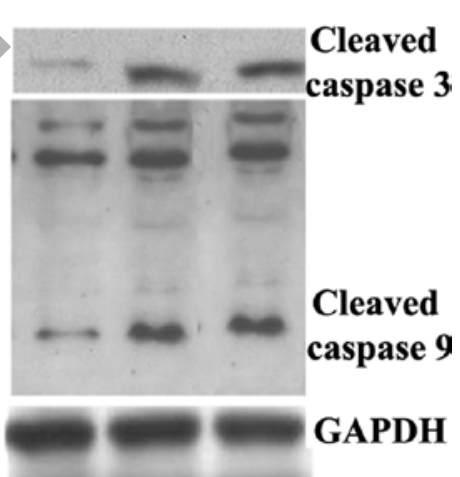

Figure 1. Radiation regulates apoptosis in human meningioma cell lines. (A) Three meningioma cell lines IOMM-Lee, MN and SF-3061 were collected after giving 5- and 10-Gy doses of $\gamma$-rays irradiation and washed three times with ice-cold phosphate-buffered saline (PBS), stained with propidium iodide ( 2 mg/ml) in $4 \mathrm{mM} / 1$ sodium citrate containing $3 \%(\mathrm{w} / \mathrm{v})$ Triton X-100 and Rnase-A $(0.1 \mathrm{mg} / \mathrm{ml})$ and were analyzed with the FACSCalibur System. The percentages of cells undergoing sub- $\mathrm{G}_{0}-\mathrm{G}_{1}$ phases were assessed using CellQuest Software. Numbers on figures represent: mean value (sub- $\mathrm{G}_{0}-\mathrm{G}_{1}$ ) of triplicate experiments. (B) Western blotting was done on total cell lysates of IOMM-Lee, MN and SF-3061 by using antibodies for caspase-3 and -9 proteins.

change in the pro- and anti-apoptotic proteins was found to be more significant in the case of pUC, when compared with control treatment (pSV) in all three cell lines (IOMM-Lee: Bcl-2, 28\%, Bcl-xL, 39\%, increase in cyt-c, 75\%; MN: Bcl-2, 84\%; Bcl-xL, 56\%, increase in cyt-c, 144\%; SF-3061: Bcl-2, $87 \%$ Bcl-xL, $84 \%$, increase in cyt-c, $81 \%$ ). However, combined treatment of pUC with irradiation was found to be relatively more effective in case of IOMM-Lee when compared with pSV+IR (Bcl-2, 75\%, Bcl-xL, 84\%, increase in cyt-c, $1958 \%$ and pU2+IR (Bcl-2, 16\%, Bcl-xL, 48\%, increase in cyt-c, 25\%) (Fig. 3). We also found that combined treatment was less effective in MN and SF-3061 cells when compared with IR control treatment and pU2+IR (Fig. 3). These findings suggest that transfection alone or in combination with radiation facilitates apoptosis in meningioma cells by increasing the expression of pro-apoptotic proteins (cyt-c) and decreasing the expression of anti-apoptotic proteins (Bcl-2 and Bcl-xL). Moreover, pUC was found to be more effective when compared to pU2 either alone or in combination with irradiation.
$R N A i$-mediated simultaneous down regulation of $u P A R$ and cathepsin B significantly induces the activation of caspases compared to other bicistronic constructs. Because the alteration in Bcl-2 is known to initiate caspase signaling, we evaluated the involvement of various caspases in apoptosis of transfected cells. Fig. 4A indicates that pUC/pU2-transfected IOMM-Lee, $\mathrm{MN}$ and SF-3061 cells induced the cleavage of initiator pro-caspases-3 and -9 in comparisons with pSV. Of the two constructs, pUC was found to be more effective either alone or in combination with irradiation in all three meningioma cell lines. Further, we measured the activity of mature caspase- 3 and -9 using a specific and sensitive colorimetric assay after transfection in all meningioma cells. Fig. 4B shows caspase-3 and -9 activities in cells transfected with scrambled vector or $\mathrm{pUC} / \mathrm{pU} 2$. Among all cells, combinatorial treatment of $\mathrm{pUC}$ and irradiation showed significant increases in the activity of mature caspase-3 and -9 in IOMM-Lee cells when compared with either control treatment (caspase-3, 2.4-fold; caspase-9, 2.6-fold), pSV+IR (caspase-3, 2.8-fold; caspase-9, 3.3-fold), 
(A)
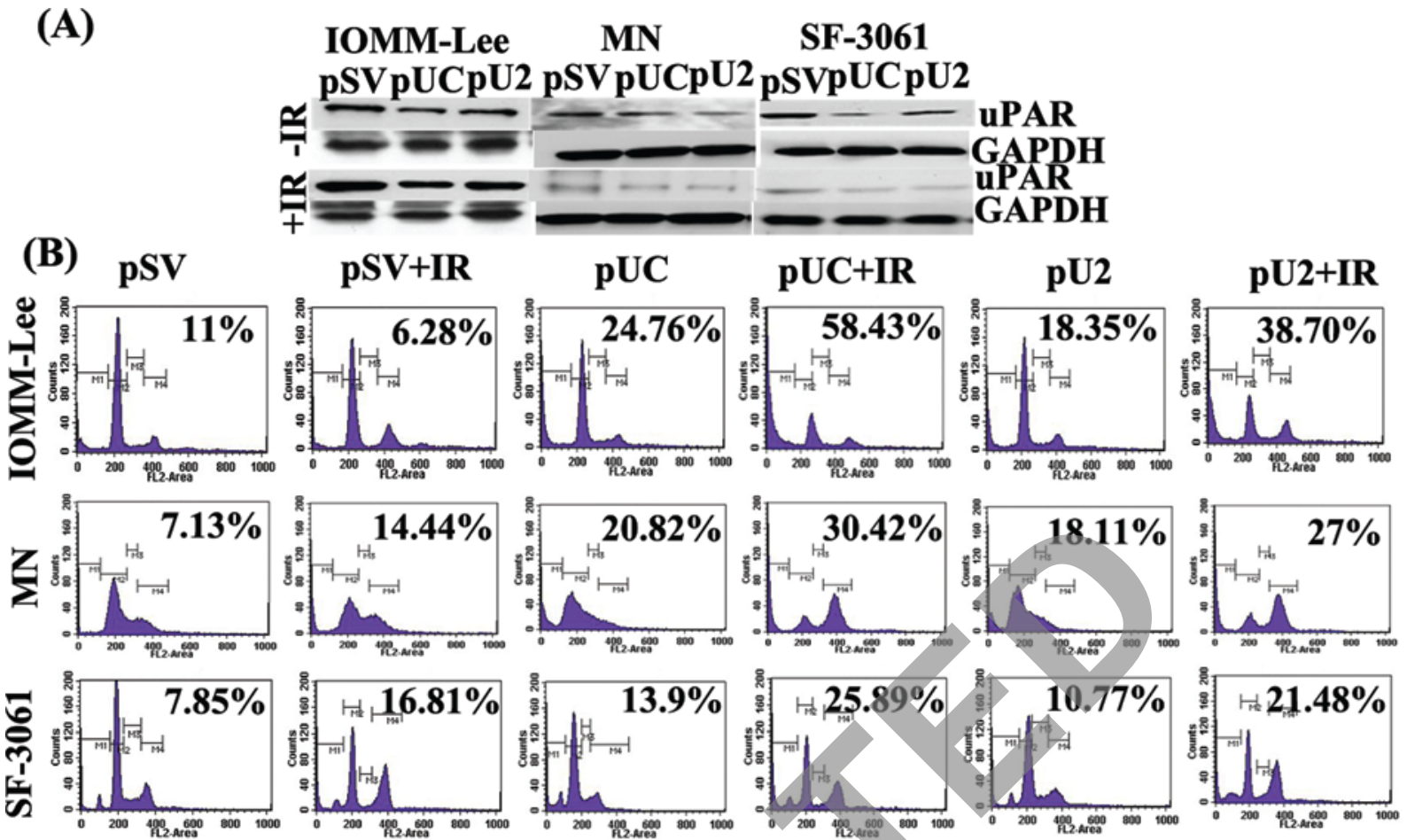

(C)

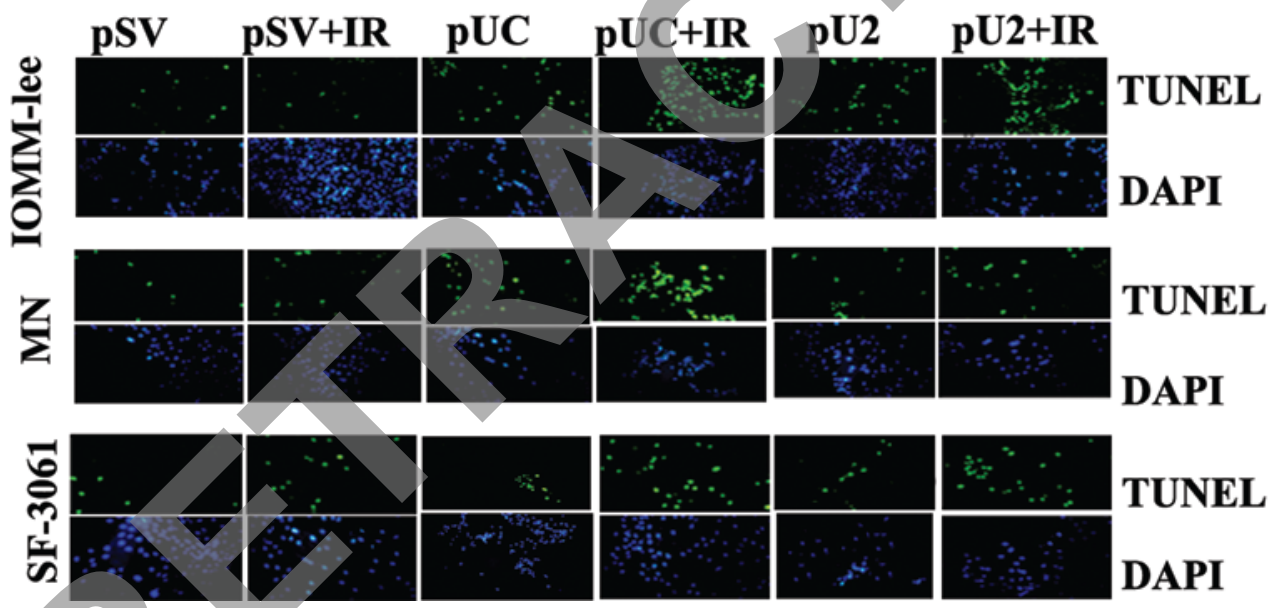

Figure 2. Bicistronic si-RNA construct of uPA, uPAR or cathepsin B induces apoptosis in meningiomas. (A) IOMM-Lee, MN and SF-3061 cells were transfected with pSV, pUC and pU2. After $48 \mathrm{~h}$ of incubation, cells were irradiated with 5 (IOMM-Lee) or $10 \mathrm{~Gy}$ (MN, SF-3061) and incubated for a further $24 \mathrm{~h}$. Cell lysates were subjected to SDS-PAGE, and immunoblot analysis was carried out to detect uPAR level. (B) Apoptosis was assessed by staining of cells with propidium iodide $(2 \mathrm{mg} / \mathrm{ml})$ in $4 \mathrm{mM} / 1$ sodium citrate containing 3\% (w/v) Triton X-100 and Rnase-A (0.1 mg/ml) and analyzing with the FACSCalibur System. The percentages of cells under sub- $G_{0}-G_{1}$ phases were assessed using CellQuest Software. Numbers on figures represent: mean value (sub- $G_{0}-G_{1}$ ) of triplicate experiments. (C) Cells were evaluated with the TUNEL assay following manufacturer's instructions and photographed under fluorescent microscopy.

pUC (caspase-3, 1.9-fold; caspase-9, 1.8-fold), pU2 (caspase-3, 1.9-fold; caspase-9, 1.8-fold) and pU2+IR (caspase-3, 1.13-fold; caspase-9, 1.18-fold). The combinatorial treatment of pUC+IR was found to be less significant in MN and SF-3061 cell lines when compared with control treatment ( $\mathrm{MN}$ : caspase-3, 1.6-fold; caspase-9, 1.86-fold; SF-3061: caspase-3, 1.8-fold; caspase-9, 2.3-fold), pSV+IR (MN: caspase-3, 1.25-fold; caspase-9, 1.5-fold; SF-3061: caspase-3, 1.4-fold; caspase-9, 1.5-fold), pUC (MN: caspase-3, 1.3-fold; caspase-9, 1.2-fold; SF-3061: caspase-3, 1.2-fold; caspase-9; 1.1-fold), pU2 (MN: caspase-3, 1.4-fold; caspase-9; 1.6-fold; SF-3061: caspase-3, 1.5-fold; caspase-9; 1.6-fold) and pU2+IR (MN: caspase-3, 1.3-fold; caspase-9, 1.25-fold; SF-3061: caspase-3, 1.15-fold; caspase-9; 1.3-fold) (Fig. 4B).

In vivo effect of $U P A, u P A R$ and cathepsin-B bi-constructs on the apoptotic molecules. To further test the role of uPA, uPAR and cathepsin B, we silenced these genes by pUC and pU2 in our in vivo assay. We found a significant decrease of uPAR in tissue lysates transfected with pUC and pU2 either alone or in combination with irradiation (Fig. 5). Our in vivo findings suggest that transfection either alone or in combination of radiation facilitates apoptosis in nude mice by increasing the expression of pro-apoptotic proteins (cytochrome c), by 

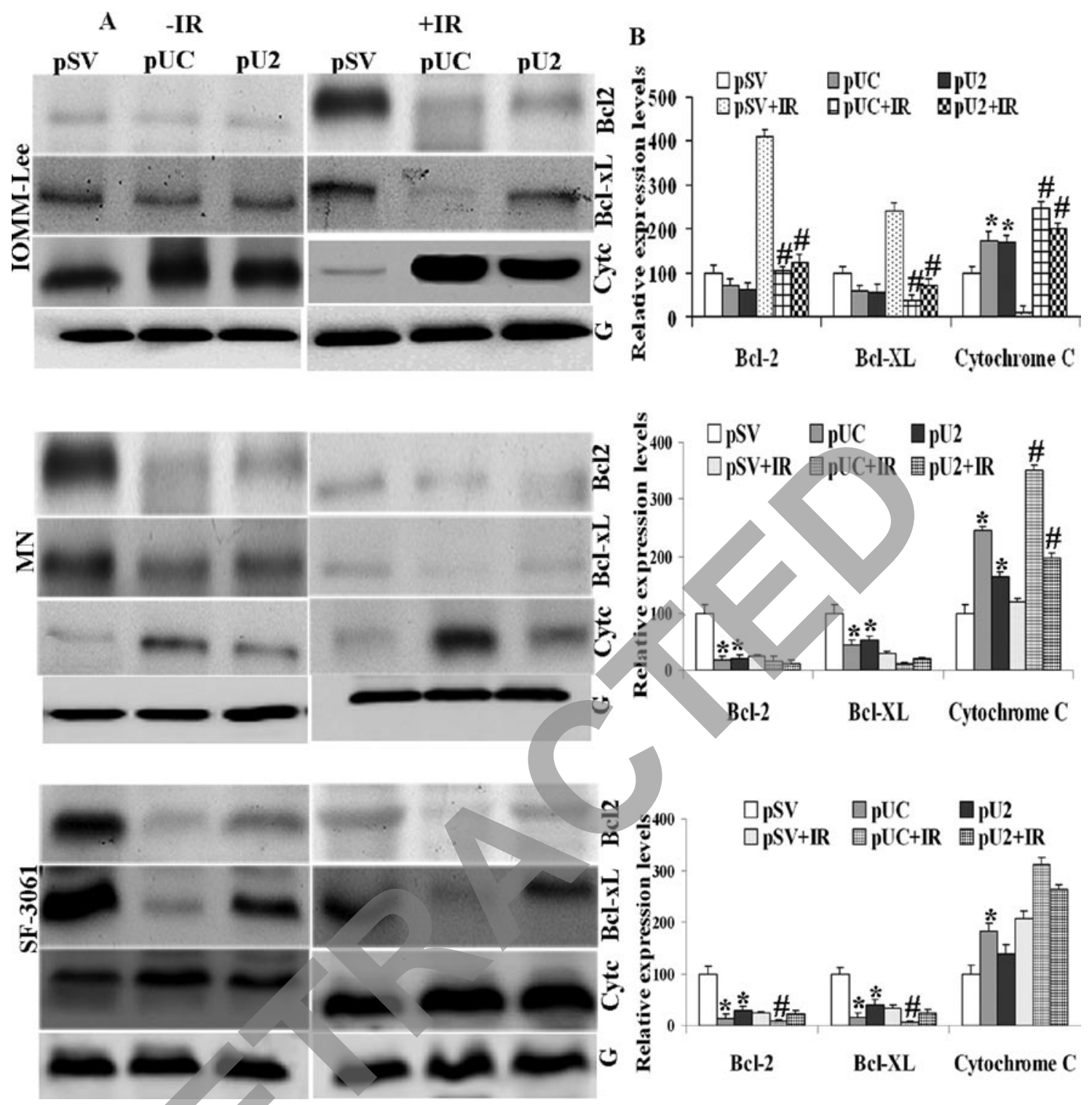

Figure 3. Simultaneous downregulation of UPA, uPAR or cathepsin B either alone or in combination with irradiation induces apoptosis by upregulation of pro-apoptotic molecules and downregulation of anti-apoptotic proteins in meningioma cells. (A) IOMM-Lee, MN and SF-3061 cells transfected with pSV, pUC and pU2 and irradiated as described earlier. Western blotting was done on total cell lysates of control and treated cells by using antibodies for proapoptotic (Cyt-c) and anti-apoptotic proteins (Bcl-2, Bcl-xL). (B) Columns represent means \pm SD of three independent experiments. * and ${ }^{\#}$ denote $\mathrm{p}<0.05$, significant difference from control and $I R$ control treatment, respectively.

decreasing the expression of anti-apoptotic proteins (Bcl-2 and $\mathrm{Bcl}-\mathrm{xL}$ ) and by cleavage of caspase- 3 and -9 . pUC in combination with irradiation was more significant when compared with pSV+IR (Bcl-2, 75\%; Bcl-xL, 84\%; cytochrome c, 50\%) and pU2+IR (Bcl-2, 23\%; Bcl-xL, 9\%; cytochrome c, 14\%) (Fig. 5).

Effect of constructs on p53 expression in vitro and in vivo. To directly evaluate the effect of uPA, uPAR and cathepsin B inhibition alone and in combination on tumor formation in vivo, we stereotactically implanted meningioma cells intracranially in nude mice. The tumors that arose were challenged with intratumoral injections of si-RNA mediated $\mathrm{pUC}$ and $\mathrm{pU} 2$ bicistronic constructs by implanting ALZET osmatic mini pumps. Histologic analysis of H\&E-stained tumor sections showed reduction of tumor volume in the brains of mice treated with either both constructs when compared with pSV-treated tumors (Fig. 6). Many apoptosis-related genes are transcrip- tionally regulated by $\mathrm{p} 53$ and are candidates for implementing p53 effector functions. In response to oncogene activation, p53 mediates apoptosis through a linear pathway involving cytochrome $\mathrm{c}$ release from mitochondria, and caspase-9 activation, followed by activation of caspase- $3,-6$, and -7 . Because p53 is a major modulator of apoptosis, we examined the status of p53 in transfected meningioma cells along with irradiation. Western blot analysis revealed $47 \%$ increases in p53 expression in irradiated IOMM-Lee cells compared to non-irradiated cells (Fig. 7A and B). We also found that treatment of cells with constructs led to reduction in the p53 expression level. This reduction was more significant in both pUC alone $(76 \%)$ or in combination with irradiation $(86 \%)$ in IOMM-Lee cells (Fig. 7B). However in MN cells, irradiation led to a decrease in p53 expression (27\%) when compared with control, making these cells radiosensitive. Further treatment with pUC+IR reduced the expression of p53 when compared 
A

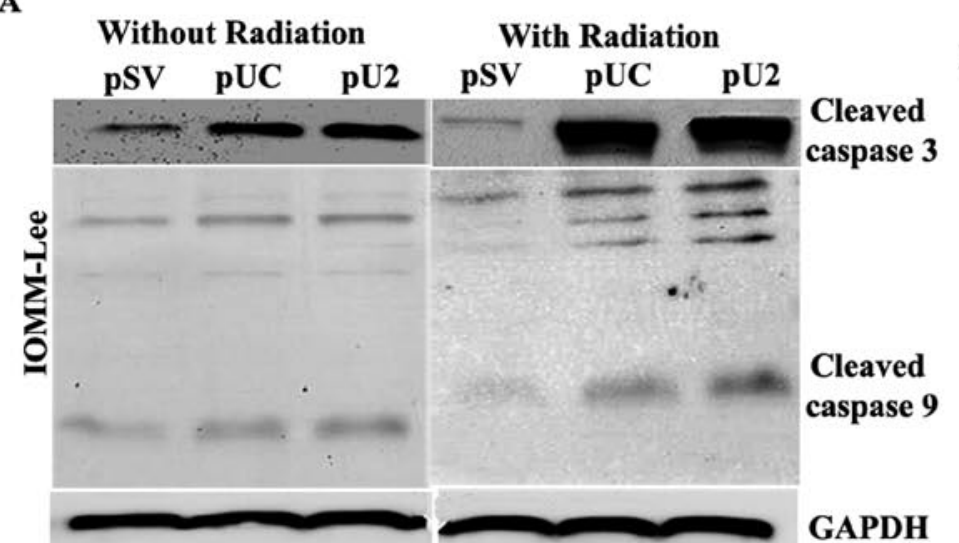

B
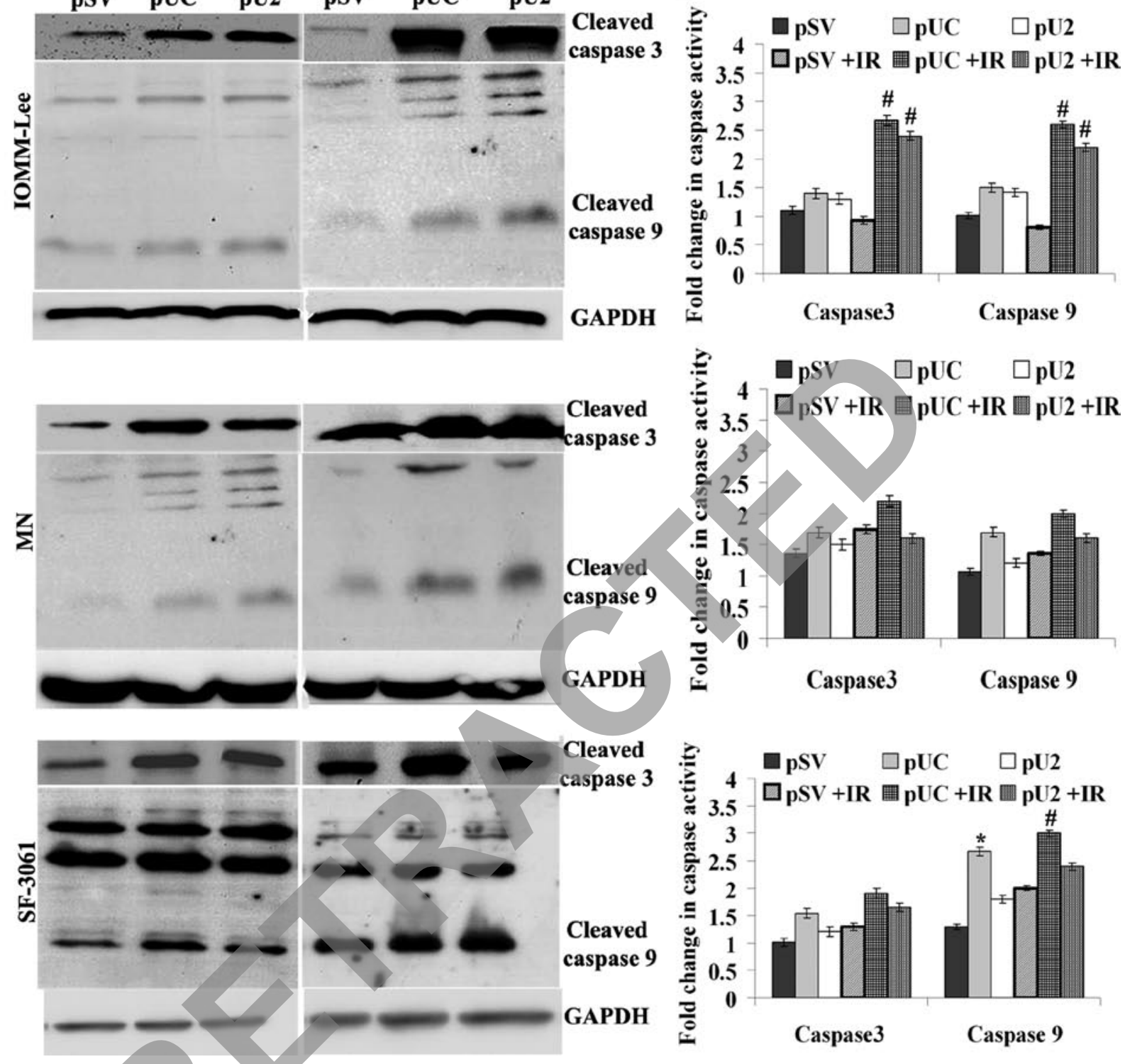

Figure 4. Simultaneous downregulation of uPA, uPAR or cathepsin B activates caspases in meningiomas (A) IOMM-Lee, MN and SF-3061 cells were transfected with pSV, pUC and pU2 and irradiated as described earlier. Equal amounts of protein from whole cell lysates of control and treated cells were analyzed by Western blotting using caspase-3 and -9 specific primary antibodies. (B) Activity assay for caspase-3 and -9 was performed in meningioma cells using a colorimetric kit as per manufacturer's instructions. The cells were cultured and transfected with or without radiation. Fold increase in caspase activity was determined by comparing the OD reading from the induced apoptotic sample with the level of the uninduced control. Data are quantitatively represented as fold increase activity of each caspase. Columns represent the means \pm SD of three independent experiments. ${ }^{*}$ and ${ }^{\#}$ denote $p<0.05$, significant difference from control and IR control treatment, respectively.

with control treatment (80\%), pSV+IR (72\%), pUC alone (23\%), pU2 (62\%) and pU2+IR (23\%). We did not study p53 in SF-3061 cell line as these cell lines are p53 negative $(29,30)$. Our in vivo studies revealed the same results showing pUC to be more effective. The expression of p53 was significantly downregulated by pUC in combination with irradiation in comparison to control treatment (81\%), pSV+IR (90\%), pUC alone (58\%), pU2 (61\%) and pU2+IR (38\%) in tissue lysates collected from nude mice (Fig. 7B).

p53 gene mutation. PCR-SSCP in vivo analysis for exons 5,7 and 8 of $\mathrm{p} 53$ showed no mutation between control and irradiated control nude mice, which clearly demonstrated that more expression of p53 in irradiated control had no association with mutations in exons 5, 7 and 8 (Fig. 7C).

In vivo effect of constructs on sub-cellular localization of p53 in nude mice. Immunofluorescence revealed that constructs led to p53 inactivation due to its sequestration in cytoplasm from the nucleus (Fig. 7D). This clearly showed p53, in its activated condition plays an oncogenic role that was suppressed by $\mathrm{pUC}$ and $\mathrm{pU} 2$ either alone or in combination with irradiation by its reshuffling from nucleus to cytoplasm.

In vivo effect of constructs on $p 38$ in nude mice. Because $\mathrm{p} 38$ is also a major modulator of apoptosis, we examined the status 
A

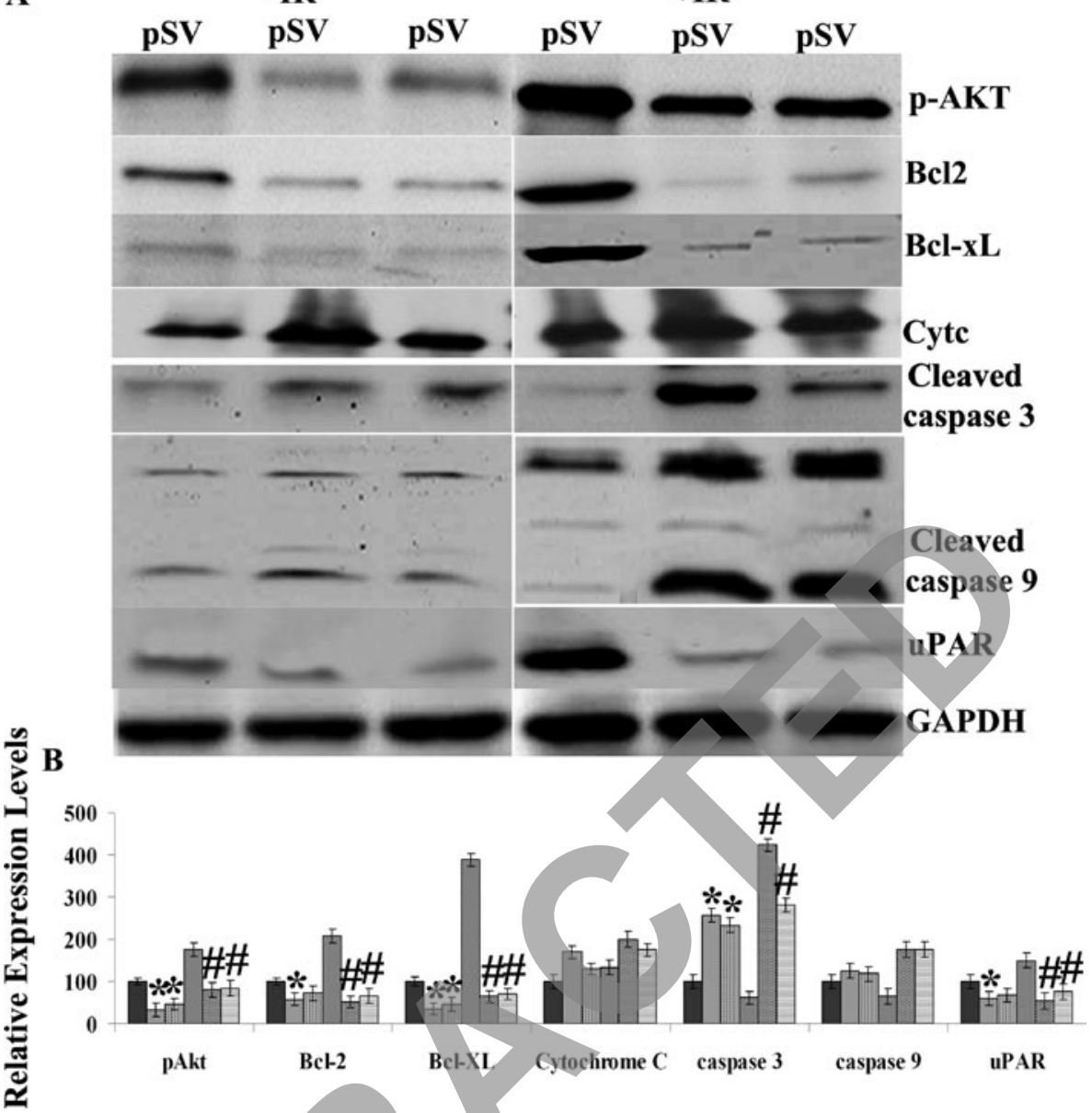

Figure 5. In vivo simultaneous downregulation of $\mathrm{UPA}$, $\mathrm{UPAR}$ and cathepsin B without or with irradiation induces apoptosis by upregulation of pro-apoptotic and downregulation of anti-apoptotic proteins. (A). Orthotopic tumors were established through intracranial injection of IOMM-Lee cells into brains of athymic nude mice. Western blotting was performed on control/treated tissue lysates by using specific antibodies for pro-apoptotic and anti-apoptotic proteins. (B) Columns represent the means \pm SD of three independent experiments. ${ }^{*}$ and ${ }^{\#}$ denote $p<0.05$, significant difference from control and IR control treatment, respectively.

of p38 in transfected meningioma nude mice along with irradiation. Western blot analysis revealed a increase in p38 expression in irradiated mice compared to non-irradiated mice. The effect of $\mathrm{pUC}$ in combination with irradiation appears to be more significant on p38 levels when compared to control treatment (696\%), pSV+IR (192\%), pUC alone (308\%), pU2 (304\%) and pU2+IR (38\%) (Fig. 7E).

\section{Discussion}

Meningiomas are the most commonly occurring brain tumors, but very little is known about the underlying molecular mechanism. About $15-20 \%$ of meningiomas exhibit a more aggressive clinical course (31). Such tumors are more likely to recur after surgical removal and may require adjuvant therapy. At present, apart from surgical resection of the tumor, radiation therapy is generally used for treatment of meningiomas and other alternative treatments are under trial. Despite intensive treatment protocols, the resistance of meningioma to current regimens including radiotherapy represents an ongoing challenge (32). This highlights the need to develop novel approaches to overcome radioresistance of meningioma and improve the dismal prognosis of this cancer (33). In recent years, the
RNAi-mediated approach has emerged as a promising scheme for the treatment of various in vivo disease models (34).

Expression of proteolytic parameters of the urokinasetype plasminogen activator system such as uPA, uPAR and cathepsin $\mathrm{B}$ has been proven to be an independent prognostic parameter in cancer. These proteolytic cascades, once modified, assist several aspects of tumorigenesis. It has been shown that the content of some tumor-associated proteolytic factors in tumor extracts have a strong prognostic value. An elevated level of cathepsin B expression has been reported at the mRNA level in prostate cancer (35), colorectal cancer (36), gliomas $(37,38)$, melanomas (39) and renal cell carcinoma (40). Previous studies performed by our group have established uPA, uPAR and cathepsin B as potential targets for therapeutic treatment of glioblastoma $(13,26)$. Our investigation uses this approach to examine the therapeutic significance of RNAimediated simultaneous downregulation of these proteases in combination with irradiation in malignant meningiomas.

As a preliminary assessment of the potential of two RNAimediated bicistronic constructs, uPAR/cathepsin B (pUC) and uPA/uPAR (pU2) as therapeutic agents in this setting, we assessed their in vitro apoptotic activity against primary meningioma cells. When transfected with bicistronic constructs, 

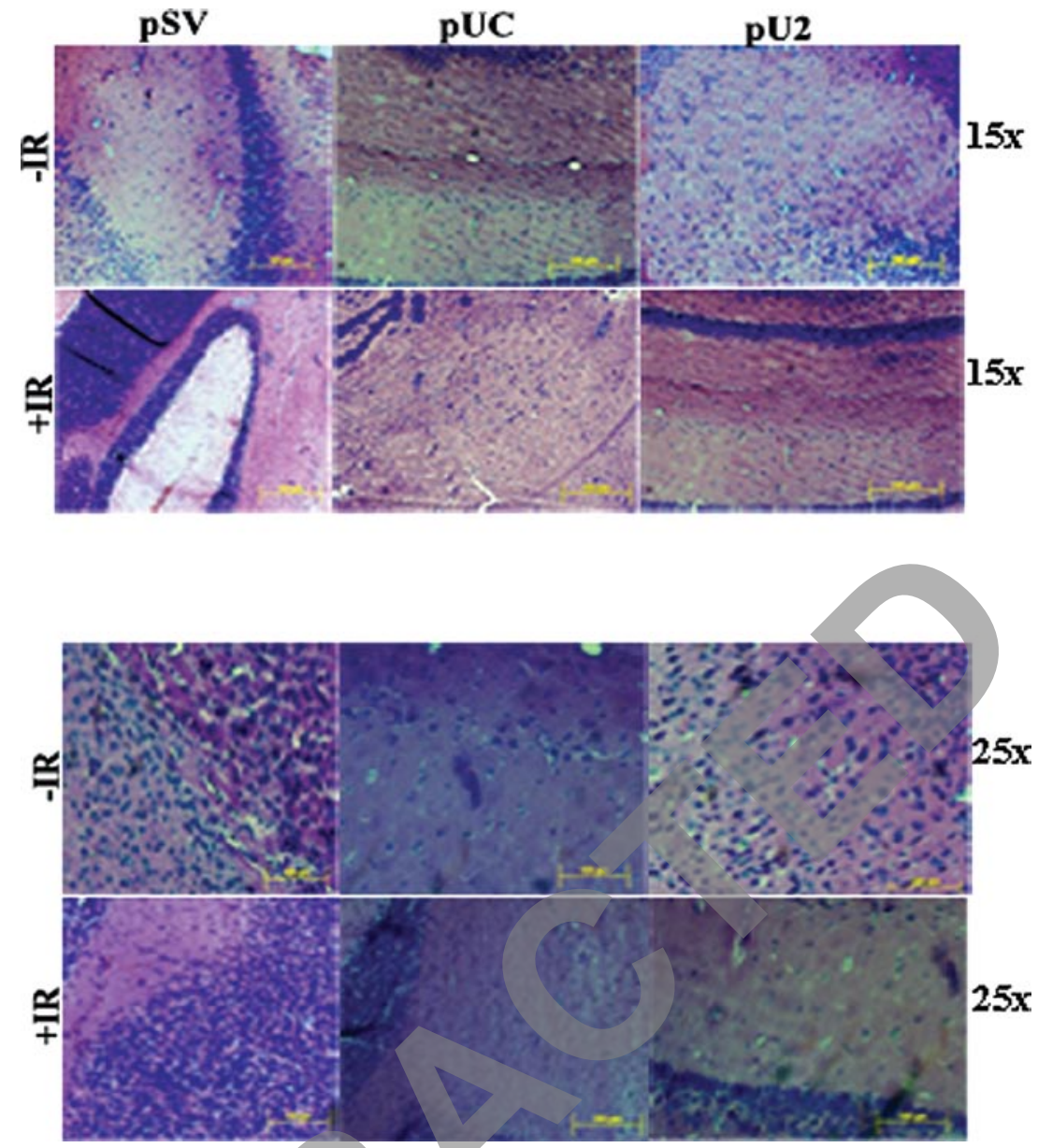

Figure 6. Tumor volume reduction by simultaneous downregulation of uPA, uPAR and cathepsin B either alone or in combination with irradiation H\&E staining was done as per standard protocol, and representative pictures of tranfected tumor sections from pSV, pUC and pU2 with or without irradiation treated mice were shown both at magnification $\times 15$ and $\times 25$.

meningioma cells became growth inhibited, rounded in morphology, and detached from the culture flask (data not shown), which are suggestive of apoptosis. Our further investigation confirmed that cell death in meningioma cells induced by transfection was mediated through induction of apoptosis, as seen by flow cytometric analysis. This apoptosis was mediated by cleavage of caspases, upregulation of pro-apoptotic protein, downregulation of anti-apoptotic proteins and to the subsequent recruitment of the intrinsic apoptotic pathway as observed by release of cytochrome c. Among the two bicistronic constructs, pUC was found to be the most effective mediator of apoptosis in all meningioma cells as confirmed by flow cytometry, TUNEL and caspase activity assay. Further we examined the combined effect of bicistronic constructs and irradiation in meningiomas. Interestingly, we observed that the combined treatment was relatively more effective in pUC-transfected cells when compared with irradiated control treatment $(\mathrm{pSV}+\mathrm{IR})$ or $\mathrm{pU} 2+\mathrm{IR}$. Based on the reductions that we observed in various aspects of tumor progression in the present study, we analyzed the in vivo efficacy of uPA, uPAR, and cathepsin B downregulation either alone or in combination with irradiation in regressing pre-established orthotopic tumors in nude mice. Our in vivo studies also revealed significant reduction in tumor volume and downregulation of anti-apoptotic molecules, indicating that these proteinases might serve as potential candidates for therapeutic targets for the treatment of malignant meningioma.

Accordingly, apoptosis induced in irradiated tumor cells could proceed in a p53-dependent manner (41). The prevention of cancer is profoundly dependent on the p53 tumor suppressor protein. p53 stimulates a wide network of signals that act through two major apoptotic pathways. The extrinsic, death receptor pathway triggers the activation of a caspase cascade, and the intrinsic, mitochondrial pathway shifts the balance in the Bcl-2 family towards the pro-apoptotic members, promoting the formation of the apoptosome and consequently caspase-mediated apoptosis. The affects of adjuvant therapies, especially radiation, on meningiomas are presently controversial (42-44). To confirm the role of p53 in the intrinsic apoptotic pathway mediated apoptosis caused by si-RNA mediated simultaneous downregulation of UPA, UPAR and cathepsin B, we performed Western blotting. We found reduced expression of p53 in transfected cells both in vitro and in vivo, which clearly shows the oncogenic role of p53 in meningiomas. We observed that apoptosis caused by bicistronic constructs is dependent of its effect on sub-cellular localization of p53. Our in vivo analysis showed reshuffling of p53 from nucleus to cytoplasm. Alternatively, because SSCP analysis is not an absolute method to demonstrate a lack of p53 gene mutation, the possibility remains that p53 gene mutations may be detected 
A
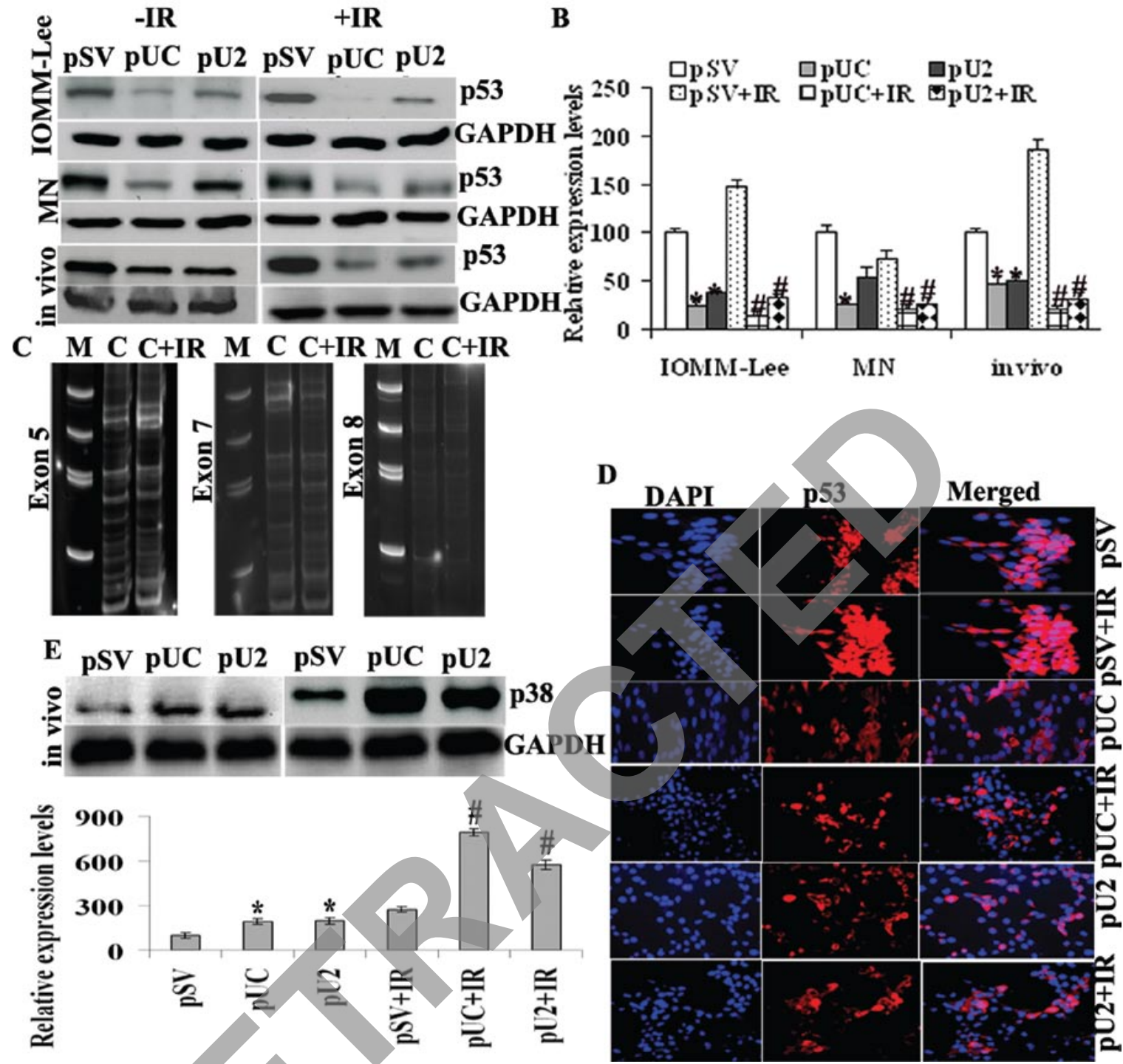

Figure 7. Oncogenic role of $\mathrm{p} 53$ is suppressed by simultaneous downregulation of uPA, uPAR and cathepsin B either alone or in combination with irradiation both in vitro and in vivo. (A) Western blotting was performed on cell/tissue lysates by using specific p53 antibody. (B) Columns represent the means \pm SD of three independent experiments. " and * denote $\mathrm{p}<0.05$, significant difference from control and IR control treatment, respectively. (C) DNA was isolated from tissue sections of non-irradiated and irradiated nude mice by the phenol-chloroform method. Exons 5, 7 and 8 inclusive of the $p 53$ gene were amplified separately by polymerase chain reaction (PCR) using specific primer pairs. The amplification products were observed using $12.5 \%$ native acrylamide gel at $200 \mathrm{~V}$ for $5 \mathrm{~h}$ by EtBr staining of $5 \mathrm{~min}$. No mutation was found between control and irradiated control treatment. (D) Immunofluorescence analysis was performed to observe sub-cellular localization of p53 in paraffin-embedded tumor sections by 2-h incubation in p53 antibody at a concentration of 1:100 at $4^{\circ} \mathrm{C}$. Slides were kept in the dark to avoid exposure to light. Fields with intense fluorescence were scored for protein expression. (E) Western blotting was performed on tissue lysates by using specific p38 antibody. Columns represent the means \pm SD of three independent experiments. * and ${ }^{*}$ denote $\mathrm{p}<0.05$, significant difference from control and IR control treatment, respectively.

in malignant meningiomas by further detailed analysis such as gene sequencing since our SSCP analysis was limited to exons 5, 7 and 8 only. We conclude that apoptosis induced by pUC and pU2 involves inactivation of p53 by its translocation to the cytoplasm from nucleus; however, pUC appears to be more effective either alone or in combination with irradiation and could thus be a potential therapeutic approach as an antitumor agent in meningioma.

\section{Acknowledgements}

This research was supported by a grant from N.I.N.D.S., NS61835 (to J.S.R.). The contents are solely the responsibility of the authors and do not necessarily represent the official views of NIH. The funders had no role in study design, data collection and analysis, decision to publish, or preparation of the manuscript. We thank Shellee Abraham for manuscript preparation, and Diana Meister and Sushma Jasti for manuscript review.

\section{References}

1. Louis DN, Scheithauer BW, Budka H, von Deimling A and Kepes JJ: Meningiomas pathology and genetics of tumours of the nervous system. In: World Health Organization Classificat Pion of Tumours. Kleihues P and Cavenee WK (eds.) IARC Press, Lyon, pp176-184. 2000. 
2. Barbaro NM, Gutin PH, Wilson CB, Sheline GE, Boldrey EB and Wara WM: Radiation therapy in the treatment of partially resected meningiomas. Neurosurgery 20: 525-528, 1987.

3. Goldsmith BJ, Wara WM, Wilson CB and Larson DA: Postoperative irradiation for subtotally resected meningiomas. A retrospective analysis of 140 patients treated from 1967 to 1990 J Neurosurg 80: 195-201, 1994.

4. Kokubo M, Shibamoto Y, Takahashi JA, Sasai K, Oya N, Hashimoto $\mathrm{N}$ and Hiraoka M: Efficacy of conventional radiotherapy for recurrent meningioma. J Neurooncol 48: 51-55, 2000.

5. Bouterfa H, Darlapp AR, Klein E, Pietsch T, Roosen K and Tonn JC: Expression of different extracellular matrix components in human brain tumor and melanoma cells in respect to variant culture conditions. J Neurooncol 44: 23-33, 1999.

6. Nakada M, Okada Y and Yamashita J: The role of matrix metalloproteinases in glioma invasion. Front Biosci 8: E261-E269, 2003.

7. Cheng JC, Chou CH, Kuo Ml and Hsieh CY: Radiation-enhanced hepatocellular carcinoma cell invasion with MMP-9 expression through PI3K/Akt/NF-kappaB signal transduction pathway. Oncogene 25: 7009-7018, 2006.

8. Speake WJ, Dean RA, Kumar A, Morris TM, Scholefield JH and Watson SA: Radiation induced MMP expression from rectal cancer is short lived but contributes to in vitro invasion. Eur J Surg Oncol 31: 869-874, 2005

9. Kunigal S, Lakka SS, Joseph P, Estes N and Rao JS: Matrix metalloproteinase-9 inhibition down-regulates radiation-induced nuclear factor-\{kappa\}B activity leading to apoptosis in breast tumors. Clin Cancer Res 14: 3617-3626, 2008.

10. Ossowski L, Clunie G, Masucci MT and Blasi F: In vivo paracrine interaction between urokinase and its receptor: effect on tumor cell invasion. J Cell Biol 115: 1107-1112, 1991.

11. Perry A, Jenkins RB, Dahl RJ, Moertel CA and Scheithauer BW: Cytogenetic analysis of aggressive meningiomas: possible diagnostic and prognostic implications. Cancer 77: 2567-2573, 1996.

12. Rempel SA, Schwechheimer K, Davis RL, Cavenee WK and Rosenblum Ml: Loss of heterozygosity for loci on chromosome 10 is associated with morphologically malignant meningioma progression. Cancer Res 53: 2386-2392, 1993

13. Gondi CS, Kandhukuri N, Dinh DH, Gujrati M and Rao JS Down-regulation of UPAR and UPA activates caspase-mediated apoptosis and inhibits the PI3K/AKT pathway. Int J Oncol 31: 19-27, 2007.

14. Huang DC and Strasser A: BH3-Only proteins-essential initiators of apoptotic cell death. Cell 103: 839-842, 2000.

15. Sionov RV and Haupt Y: The cellular response to p53: the decision between life and death. Oncogene 18: 6145-6157, 1999.

16. Ali IU, Schweitzer JB, Ikejiri B, Saxena A, Robertson JT and Oldfield EH: Heterogeneity of subcellular localization of p53 protein in human glioblastomas. Cancer Res 54: 1-5, 1994.

17. Eyfjord JE, Thorlacius S, Steinarsdottir M, Valgardsdottir R, Ogmundsdottir HM and Namthawat-Jonsson K: p53 abnormalities and genomic instability in primary human breast carcinomas. Cancer Res 55: 646-651, 1995.

18. Hoppe-Seyler F and Butz K: Tumor suppressor genes in molecular medicine. Clin Invest 72: 619-630, 1994

19. Louis DN, von DA, Chung RY, Rubio MP, Whaley JM, Eibl RH, Ohgaki H, Wiestler OD, Thor AD and Seizinger BR: Comparative study of p53 gene and protein alterations in human astrocytic tumors. J Neuropathol Exp Neurol 52: 31-38, 1993.

20. Porter PL, Gown AM, Kramp SG and Coltrera MD: Widespread p53 overexpression in human malignant tumors. An immunohistochemical study using methacarn-fixed, embedded tissue. Am J Pathol 140: 145-153, 1992.

21. Starzynska T, Markiewski M, Domagala W, Marlicz K, Mietkiewski J, Roberts SA and Stern PL: The clinical significance of p53 accumulation in gastric carcinoma. Cancer 77: 2005-2012, 1996.

22. Prayson RA: Malignant meningioma: a clinicopathologic study of 23 patients including MIB1 and p53 immunohistochemistry. Am J Clin Pathol 105: 719-726, 1996.

23. Matsuno A, Nagashima T, Matsuura R, Tanaka H, Hirakawa M, Murakami M, Tamura A and Kirino T: Correlation between MIB-1 staining index and the immunoreactivity of p53 protein in recurrent and non-recurrent meningiomas. Am J Clin Pathol 106: 776-781, 1996.
24. Kerr JF, Wyllie AH and Currie AR: Apoptosis: a basic biological phenomenon with wide-ranging implications in tissue kinetics. Br J Cancer 26: 239-257, 1972.

25. Vassalli JD, Sappino AP and Belin D: The plasminogen activator/ plasmin system. J Clin Invest 88: 1067-1072, 1991.

26. Lakka SS, Gondi CS, Yanamandra N, Olivero WC, Dinh DH, Gujrati M and Rao JS: Inhibition of cathepsin B and MMP-9 gene expression in glioblastoma cell line via RNA interference reduces tumor cell invasion, tumor growth and angiogenesis. Oncogene 23: 4681-4689, 2004

27. Rao JS, Bhoopathi P, Chetty C, Gujrati M and Lakka SS: Matrix metalloproteinase-9 short interfering RNA induced senescence resulting in inhibition of medulloblastoma growth via $\mathrm{p} 16^{\mathrm{INK} 4}$ and mitogen-activated protein kinase pathway. Cancer Res 67: 4956-4964, 2007.

28. Brockmann MA, Westphal M and Lamszus K: Improved method for the intracerebral engraftment of tumour cells and intratumoural treatment using a guide screw system in mice. Acta Neurochir (Wien) 145: 777-781, 2003.

29. Bostrom J, Meyer-Puttlitz B, Wolter M, Blaschke B, Weber RG, Lichter P, Ichimura K, Collins VP and Reifenberger G: Alterations of the tumor suppressor genes CDKN2A [p16(INK4a)], p14(ARF), CDKN2B [p15(INK4b)], and CDKN2C [p18(INK4c)] in atypical and anaplastic meningiomas. Am J Pathol 159: 661-669, 2001

30. Simon M, Park TW, Koster G, Mahlberg R, Hackenbroch M, Bostrom J, Loning T and Schramm J: Alterations of INK4a(p16$\mathrm{p} 14 \mathrm{ARF} / \mathrm{INK} 4 \mathrm{~b}(\mathrm{p} 15)$ expression and telomerase activation in meningioma progression. J Neurooncol 55: 149-158, 2001.

31. Modha A and Gutin PH: Diagnosis and treatment of atypical and anaplastic meningiomas: a review. Neurosurgery 57: 538-550, 2005.

32. Kyritsis AP: Chemotherapy for meningiomas. J Neurooncol 29: 269-272, 1996

3. Park HS, Yun Y, Kim CS, Yang KH, Jeong M, Ahn SK, Jin YW and Nam SY: A critical role for AKT activation in protecting cells from ionizing radiation-induced apoptosis and the regulation of acinus gene expression. Eur J Cell Biol 88: 563-575, 2009.

34. Gondi CS, Lakka SS, Dinh D, Olivero W, Gujrati M and Rao JS: Downregulation of UPA, UPAR and MMP-9 using small, interfering, hairpin RNA (siRNA) inhibits glioma cell invasion, angiogenesis and tumor growth. Neuron Glia Biol 1: 165-176, 2004.

35. Sinha AA, Gleason DF, Deleon OF, Wilson MJ and Sloane BF: Localization of a biotinylated cathepsin B oligonucleotide probe in human prostate including invasive cells and invasive edges by in situ hybridization. Anat Rec 235: 233-240, 1993.

36. Murnane MJ, Sheahan K, Ozdemirli M and Shuja S: Stagespecific increases in cathepsin B messenger RNA content in human colorectal carcinoma. Cancer Res 51: 1137-1142, 1991

37. Rempel SA, Rosenblum Ml, Mikkelsen T, Yan PS, Ellis KD, Golembieski WA, Sameni M, Rozhin J, Ziegler G and Sloane BF: Cathepsin B expression and localization in glioma progression and invasion. Cancer Res 54: 6027-6031, 1994.

38. Sivaparvathi M, Sawaya R, Wang SW, Rayford A, Yamamoto M, Liotta LA, Nicolson GL and Rao JS: Overexpression and localization of cathepsin B during the progression of human gliomas. Clin Exp Metastasis 13: 49-56, 1995.

39. Frohlich E, Schlagenhauff B, Mohrle M, Weber E, Klessen C and Rassner G: Activity, expression, and transcription rate of the cathepsins $\mathrm{B}, \mathrm{D}, \mathrm{H}$, and $\mathrm{L}$ in cutaneous malignant melanoma. Cancer 91: 972-982, 2001.

40. Shetty $\mathrm{S}$ and Idell S: Urokinase induces expression of its own receptor in Beas2B lung epithelial cells. J Biol Chem 276: 24549-24556, 2001.

41. Haupt S, Berger M, Goldberg Z and Haupt Y: Apoptosis - the p53 network. J Cell Sci 116: 4077-4085, 2003.

42. Jaaskelainen J, Haltia M and Servo A: Atypical and anaplastic meningiomas: radiology, surgery, radiotherapy, and outcome. Surg Neurol 25: 233-242,1986.

43. Mahmood A, Caccamo DV, Tomecek FJ and Malik GM Atypical and malignant meningiomas: a clinicopathological review. Neurosurgery 33: 955-963, 1993.

44. Mahmood A, Qureshi NH and Malik GM: Intracranial meningiomas: analysis of recurrence after surgical treatment. Acta Neurochir (Wien) 126: 53-58, 1994. 